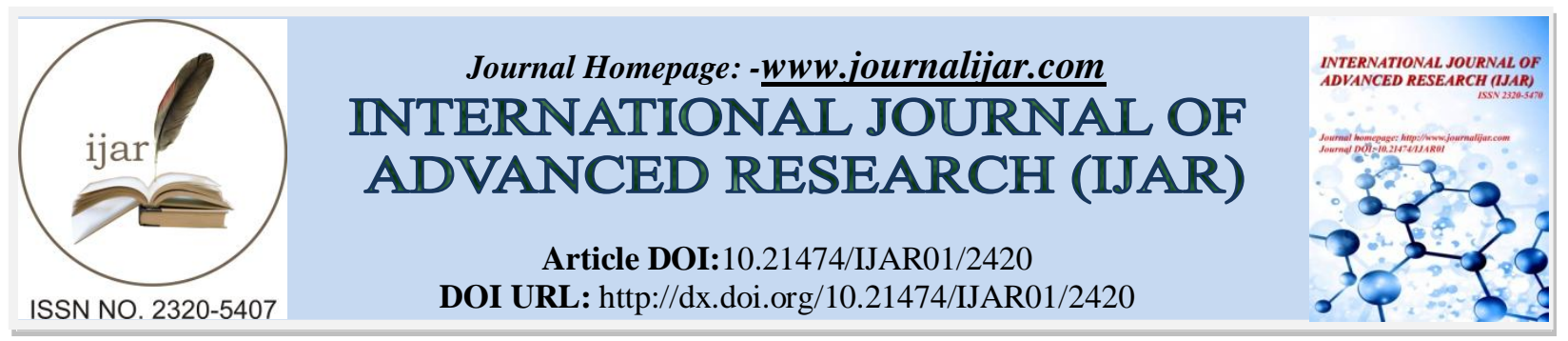

RESEARCH ARTICLE

\title{
EVALUATION OF ENVIRONMENTAL COSTS OF ENTERPRISES WITHIN ENVIRONMENTAL ACCOUNTING IN TERMS OF PERSONALITY CONCEPT.
}

Eray Cetin.

Osmaniye Korkut Ata University, Turkey.

\section{Manuscript Info}

Manuscript History

Received: 20 October 2016

Final Accepted: 22 November 2016

Published: December 2016

Key words:-

Environment, Environmental Costs,

Environmental Accounting, Personality

Concept.

\section{Abstract}

Personality is defined by the Turkish Language Association as the whole habits and behavior of an individual acquired through social life. Considering the basic concepts of accounting, businesses have different personalities than those of their owners or partners. Therefore, when assessing the activities of a company, their own personalities are considered. In this context, businesses constantly interact with their environment as separate entities. In today's world, the number of enterprises engaged in production for growing markets due to globalization and production processes containing advanced technology and the number and diversity of products have interconnectedly increased. Enterprises have a close relationship with their environment in both production and post-production processes because of the natural resources they need to acquire in pre-production period. During these processes enterprises must consider and analyze various environmental costs stemming from their being separate entities and include these costs in their activity coverages. The aim of this study is to emphasize that environmental costs of enterprises must be financially expressed and scrutinized due to the concept of personality.

Copy Right, IJAR, 2016,. All rights reserved.

\section{Introduction:-}

In time, companies act for meeting human needs undergo structural and administrative changes and also shareholders of companies are enlarged. In the beginning, company activities are important for only shareholders; nowadays they appeal to large crowd of people. Accordingly, shareholders, managers, workers, suppliers, creditor institutions, customers, public company shareholders are approached in this. Actually environment is another concept that also needs to be in these shareholders. Because environment is a matter of fact that directly affects from company activities and directly effects company activities. Therefore, if it is thought that environment is also in company shareholders, environment shall also directly adapt with companies' stature. Just like every individual within the society, companies also shall give particular importance to social responsibility in accordance with their statures and shall carry out their activities according to this. So then beside companies maximize their benefits, according to their social responsibilities they shall act environment-conscious, minimize environmental damages and make rehabilitation works without making environmental condition worse and make this sustainable. So both environment and also company effect positively from the environment. 


\section{Company and Concept of Stature:-}

Various descriptions take place for company in literature. Company can be described as; a social, an economic and a technical unit which deliberately, consciously and systematically combines labor, capital and other manufacture factors and tends towards manufacturing goods and service and makes economic and rational decisions in usage of manufacturing sources to reach their goals (Şimşek and Çelik, 2008). According to concept of stature, one of the generally accepted accounting principles, it has a stature differs from owner or owners, managers and other authorities and all accounting transactions must be done on behalf of only this stature (Gücenme, 1996).

\section{Company and Environment:-}

And also one of the typical properties of the company is undertaking manufacturing activities which are community oriented and will meet community needs. In this structure company shall be seemed as an economic unit and at the same time as a social unit that takes out to gain profit (Sabuncuoğlu and Tokol, 1997). Companies acting in social structure are always in interactive relation with the environment.

Companies need natural sources during their manufacturing goods and service and being insufficient or not in environment where the company resides affects on site of establishment of company and performance positively or negatively (Ünsalan and Şimşeker, 2006). If we describe it with an example; in accordance with soil and water pollution, while efficient agricultural lands getting acidified will restrict companies' agricultural activities. Suchlike this, in addition to soil and water pollution, if there has also air pollution, in parallel with this negatively effects on tourism and this will restrict tourism companies' activities. Especially, by changing over from labor-intensive system to mechanical-intensive system with industrial revolution, production quantities are increasing and also environmental factors affect negatively from this. As a result of extreme environment pollution, living quarters are restricted and the concept of environmental consciousnessrises.

In this context, also companies start to take either voluntarily or repressive precautions to prevent environmental pollution. These precautions cause cost increase from the point of companies and they are awarded as being conscious customers' choice (Akgemci and Güleş, 2009).

\section{Environmental Accounting:-}

Accounting is mostly described as a science which makes changes in assets, sources, incomes and outcomes of company due to mutual relations between companies and internal events, fully or partially saves and classifies information about fiscal natural transactions and comments conclusions by summarizing significantly and therefore provides useful information suitable for their goals to company authorities (Sürmen, 2012). Thereby, transactions included in the scope of accounting are related with companies' self-statures.

Ecosystem of the World becoming unbalanced in accordance with environmental pollution and viciously usage of natural sources is increasing environmental conscience. Therefore concept of environmental accounting is becoming a current issue by following the activities and environmental costs of companies acting in natural environment.

Environmental accounting can be described, also pursuant to the description of accounting, as an information system which produces information about formation of environmental sources, usage manner of these sources, increases and decreases in these sources at the end of companies' activities and environmental status of companies; and transmits these to regarding person and institutions (Özbirecikli, 2002).

\section{Environmental Costs:-}

Together with the developing environment understanding, the environment oriented activities of the enterprises and accordingly their costs in environmental means increase. Therefore, these costs should not be followed among other costs or general costs but should be evaluated under a separate headline. The main headline for this kind of costs is environmental costs. (Özbirecikli, 2002).

All kinds of activities performed by enterprises for environment causes environmental costs to occur and accounting of these costs among other activities of the enterprise discursively is against the significance principle of accounting which is one of the basic principles. (Kırlığlu, 2011).

Environmental costs may vary according to their appearance types. From this point of view the environmental costs can be gathered under three main headlines; these are reducing costs, usage costs and loss costs. While reducing costs includes the costs the enterprises bear for preventing or reducing the environmental problems, usage costs 
include the costs that enterprises bear in return of using environmental resources and loss costs include the costs that enterprises bear due to environmental pollution or environmental damage occurring as a result of operational activities. (Kırlığlu and Can, 1998).

\section{Conclusion:-}

The factors that the enterprises acting within today's economic system need to take into consideration have increased. Now the enterprises are not only entities that are satisfied with realizing production and sales but have become social entities. Strategical management understanding has been adopted by enterprises and in this scope vision and mission is determined and the activities are being conducted within the scope of these. In light of all these, it is not possible to consider the enterprises which have become social entities, to act in an activity understanding which is distant and independent from environment. Because enterprises and environment mutually and continuously influence each other. Detecting and preventing the problems that will arise from this interaction or minimizing the losses that may occur is among the necessities of the strategic management understanding. If we consider that each enterprise has an independent personality, enterprises, just like individuals living in the same environment, need to pay maximum attention on their activities and minimize the environmental damages. In order to achieve this, enterprises need to determine their environmental costs separately from their other activities and it will be convenient for them to incorporate these into a separate environmental reporting system. The expenses made by the enterprises related with environment increase their costs. However, as the environmental investments realized by enterprises today, decrease the created waste and environmental pollution and also reduce natural resource consumption, it seems to be positive under the scope of cost benefit from general economy perspective. As the environmental costs of enterprises increase it will be difficult for them to incorporate them to their existing accounting system and follow them so it is necessary for them to handle and evaluate environmental costs in another system, namely environmental accounting.

All environmental activities to be realized on the enterprise side and all related costs that may occur are directed with the enterprise itself. Therefore, considering that enterprises are separate personalities, it is necessary for enterprises to associate and evaluate all factors regarding environment with their own personalities.

\section{References:-}

1. AKGEMCI, T. ve GÜLEŞ, H., K., (2009), İşletmelerdeStratejikYönetim, GaziKitabevi, Ankara.

2. GÜCENME, Ü., (1996),TekdüzenHesapPlanınaGöreTicariİşletmelerdeMuhasebeveEnvanterişlemleri, Marmara KitabeviYayınları, Bursa.

3. KIRLIOĞLU, H., (2011), İşletmelerdeÇevreselMaliyetlerveBirUygulama, AkademikYaklaşımlarDergisi, Cilt:2, Say1: 1,

4. KIRLIOĞLU, H. ve CAN, A., V., (1998),ÇevreMuhasebesi, DeğişimYayınları, Adapazarı.

5. ÖZBİRECIKLİ, M., (2002), ÇevreMuhasebesi, NatürelKitapveYayıncılık, Ankara.

6. SABUNCUOĞLU, Z. ve TOKOL, T., (1997), İşletme I-II, FurkanOfset, Bursa.

7. SÜRMEN, Y., (2012),Muhasebe-I, CeleplerMatbaacillk, Trabzon.

8. ŞİMŞEK, Ş. Ve ÇELIKK, A., (2008), Genelİşletme, EğitimAkademiYayınları, Konya.

9. ÜNSALAN, E. Ve ŞIMMŞEKER, B., (2006), Temeli̇şletmecilikBilgileri, DetayYayıncılık, Ankara. 